Cinémas

Revue d'études cinématographiques

Journal of Film Studies

\title{
The Photographic Insane
}

\section{Kathryn Fraser}

Volume 9, numéro 1, automne 1998

Les Dispositifs de médiation au cinéma

URI : https://id.erudit.org/iderudit/024777ar

DOI : https://doi.org/10.7202/024777ar

Aller au sommaire du numéro

Éditeur(s)

Cinémas

\section{ISSN}

1181-6945 (imprimé)

1705-6500 (numérique)

Découvrir la revue

Citer cet article

Fraser, K. (1998). The Photographic Insane. Cinémas, 9(1), 139-151.

https://doi.org/10.7202/024777ar

\section{Résumé de l'article}

Le célèbre essai de Bazin concernant l'identification de la photographie en fonction de son sujet relevait des liens des premières photographies avec les expérimentations des sciences humaines (la psychiatrie). Contrairement à cette tendance l'auteure développe, dans ce texte, le point de vue selon lequel la perception est reliée à un processus conceptuel. Cet article constitue une courte examination de ce que l'auteure appelle the photographie insane et illustre comment les images de la folie utilisent et demandent pour leur interprétation une construction "schématique " particulière et partagée culturellement. 


\title{
The Photographic Insane
}

\section{Kathryn Fraser}

\begin{abstract}
RÉSUMÉ
Le célèbre essai de Bazin concernant l'identification de la photographie en fonction de son sujet relevait des liens des premières photographies avec les expérimentations des sciences humaines (la psychiatrie). Contrairement à cette tendance l'auteure développe, dans ce texte, le point de vue selon lequel la perception est reliée à un processus conceptuel. Cet article constitue une courte examination de ce que l'auteure appelle the photographic insane et illustre comment les images de la folie utilisent et demandent pour leur interprétation une construction "schématique" particulière et partagée culturellement.
\end{abstract}

\begin{abstract}
Bazin's famous essay touting the photograph's identicality with its subject was precedented by photography's early relation to empirical investigation in the human sciences (the psychiatry). Contrary to this, what this author wishes to reinforce in this paper is that perception is constructed and integrally bound up with conceptual processes. This paper thus constitutes a short examination of what this author calls the "Photographic Insane, " and illustrates how images of madness use, and require for their interpretation, a particular, and culturally shared "schematic" framework.
\end{abstract}

Images of madness are by now familiar to us. We have all encountered, at one time or another, someone whose gestures or facial expressions are recognizable to us as insane. Whether through our personal experience of the crowded urban landscape in which we live and work, or through images rendered in 
literature, painting, photography, and cinema, the features of madness seem imminently accessible. The move from artistic representations of madness to the science of physiognomy employed in the service of medical illustration constitutes a significant shift in both established modes of perception as well as in the motivation behind the production of such images. The introduction of photography to the clinical gaze, ' which might be seen to have instigated a return to eighteenth-century positivism, first occurred in the field of psychiatry - a discipline not usually considered in terms of its empirical potential. Photography's early - and we might say somewhat sustained - status as an objective medium has imbued it with a particular authority when representing to us the human form in all of its manifestations. There is, in the tradition of medical imaging and in early photographic studies used to set up indices of normalcy and deviance (I am thinking here of the movement studies executed by Jules Marey and others), the assumption that perception is ahistorical, disinterested, and objective. Contrary to this, what I wish to reinforce here is that perception is constructed and integrally bound up with conceptual processes. This is not to deny the veracity of our "direct" visual (or aural ${ }^{2}$ ) experience of mental illness. Rather, it is necessary to acknowledge the ways in which "ideas" about madness have historically shaped, and continue to inform, its representations and the technologies used to do so.

My interest in what I have called the "Photographic Insane" was first inspired by the "before" and "after" pictures of Christine and Léa Papin, two domestics who, in the town of Le Mans, France, in 1933, brutally murdered their employer and her daughter. The images are intended to represent the sisters at a time first, of mental stability, and then, of extreme psychic trauma. The interval between the two images is therefore supposed to designate a transformation from apparent normalcy to visually perceptible deviance. In fact, one of the original purposes of psychiatric photography was to ease a growing public anxiety with respect to the increasing dangers associated with an ever-expanding social arena. Psychiatric (as well as criminal) photography and physiognomy promised to educate a nervous 
public about who they could and could not trust on the urban scene. The problem with such an aim, as we have seen with "actual" psychotics such as Jeffrey Dahmer or Paul Bernardo, is that they succeed in their crimes precisely because they "appear" to be "no different" from us. Thus how do we account for the normalcy of the first image which made the violence preceding the second image possible? In other words, if mental illness is so readily available to the "naked eye" of the camera, why wasn't it available to the Papin's victims - Mme and Mlle Lancelin - who might then have been able to save their own lives?

I submit that what the Papin photographs (as well as many other photographic instances of insanity) represent is not madness, but the photographic code, or "schema" of madness. The concept of "schema" proposed by Ernst Gombrich explains both how we are able to recognize shapes / faces / etc., as familiar, as well as how visual representation can consist of as complex a system of codes as verbal language. Schemata regulate perception and allow us to impose the familiar on the less familiar through the incorporation of generalized or pre-existing categories. "The schema is not the product of a process of 'abstraction,' or a tendency to 'simplify;' it represents the first approximate, loose category which is gradually tightened to fit the form it is to reproduce." (1960, p. 74)

Schemata thus also function to create "types," the recognition of which depends on a viewing subject's understanding of visual difference: "For it is not really the perception of likeness for which we have been programmed, but the "noticing of unlikeness'." (p. 13) Recognition is therefore relative: it is informed by past experience, and by our expectation that an external image will always be different from oneself. In fact, Gombrich goes so far as to say that we may actually "produce" visual characteristics in an image as a result of our need to make sense of, or to distinguish ourselves from, it: "We tend to project life and expression onto the arrested image and supplement from our own experience what is not actually present." (p. 17) The reliability of an image, then, is based more on how well it corresponds to our belief system than on how neatly it conforms 
to the "actual" physical dimensions of the object it represents. For example, prior to the eighteenth century, representation tended toward depictions of medical procedure such as removing the "stone of madness." Not yet conceptualized as an "invisible" disease, insanity was imagined as being located in a stone which necessitated removal if the patient was to be cured. This fictive symptom "[was] a means of representing an invisible state." (Gilman, 1988, p. 19) It also, however, served the function of alleviating anxiety about mental illness: if it could be solved by a "simple" operation (that is, if one lived through it), then it wouldn't represent as great a threat to the social order.

Perhaps most importantly, as Sander Gilman has shown, for all representations of madness whatever the historical framework, is the tendency to represent the insane as "other." Alterity has always functioned as a source of anxiety, and the fears of a society are usually projected onto whoever the "other" happens to be at any given moment. One of the images of madness in the Middle Ages, for example, delineated the terrain of insanity as animal and wild. Madness was conceptualized as bestial with the sufferer in a perpetually feral state. Later, during the Renaissance, the mad were displayed in cages set up in the streets, or were visible through the bars on the windows of their cells in the as yet unreformed asylums. In fact, up until the early nineteenth century, Foucault tells us, some asylums even charged admission to behold the spectacle of the insane. Like animals on display in a zoo, the mentally ill were furnished with only a bit of straw, and were usually only barely - if at all clothed. The idea was that, like animals, the mad were indifferent to their surroundings; to such things as fluctuations in temperature, or the stench or their own refuse. Unable to conceive of man without rational thought (indeed, without thought at all), the Enlightenment could only understand madness as bestial: "[...] madness in its ultimate form is man in immediate relation to his animality, without other reference, without recourse." (Foucault, 1965, p. 74) Further, since the mad were considered to reside in a perpetually feral state, literary and artistic representations showed the madman with long, claw-like 
nails, and he was hirsute. It is equally important to note the equation of darkness with madness and to remember that the experience of racial alterity was tightly bound up with a strong eurocentrism : cultural / religious deviation was equated with savagery, barbarousness. Mediterraneans, blacks - anyone with darker skin than the central European - were thus conceptualized in animal terms.

Still, as a consequence of the new emphasis on scientism initiated in the eighteenth century, the view of madness as animality gradually came to be replaced by the view of madness as disease. Since the tenets of the Enlightenment stated that reason was "the" natural, ontological condition of "man," it was believed that the insane could be restored to sanity through rigourous observation. To quote Michel Foucault: "We know the images. They are familiar in all histories of psychiatry, where their function is to illustrate that happy age when madness was finally recognized and treated according to a truth to which we had long remained blind." (1965, p. 141) Of course, Foucault is referring to the changes in the asylum in the nineteenth century which closed its doors on the public and put a stop to the "commodification" of the mentally ill. Preceding these reforms, however, were a number of innovations which paved the way for madness to be understood not as wholly other, but as a deviation from the normal. Instrumental to this notion was the rediscovery of classical physiognomy by Johann Caspar Lavater in the 1770 's. In its application to mental illness in the eighteenth century, physiognomy " $[. .$.$] captured the popular fancy of all$ Europe" (Gilman, 1988. p. 25) since it promised to reconcile the previous opposition postulated between mind and body now increasingly under scrutiny. The unique workings of the mind, it was believed, could be ascertained through physical features.

In keeping with eighteenth-century notions of individuality, representation took a swift turn in the direction of portraiture and henceforward madness seems to have become individualized. Images now functioned as maps with the anatomies of idiocy and madness clearly demarcated by various and conspicuous physiological features. Further, the patient needed only to 
recognize himself in the image of insanity and to note his difference from images of "normalcy" in order to restore himself to reason and sanity. The use of codes of portraiture (e.g. image limited to representing the head and shoulders on a plain or non-existent background) and the choice to represent a posed subject rather than an arrested moment in time (such as a surgical procedure) all contributed to the increasing medicalization of such images. It also, however, had the effect of creating a visual model rather than representing a psychological state. This model would become very important in the nineteenth century's discovery of the archival potential of the "photographic insane." The move from representing mental illness in aesthetic terms (as in images of surgery or bestiality) to representing it as a disease suffered by a living person (as in medical illustration or physiognomy) aided a practical purpose to be realized in the nineteenth century: that of recognition through the construction of visual "types."

The nineteenth century inaugurated a period of intensive urbanization. To meet the ever-increasing need to populate the factories, the cities expanded rapidly bringing together (at least spatially) people from previously unassimilable groups. Judith Walkowitz, in her study of "late-Victorian London," also notes the erosion of the physical boundaries separating class from class (urban from rural, etc.) as having been facilitated, in part, by technologies devoted to a viewing subject (I am thinking here of innovations in architecture and, of course, photography). Various marginalized groups, she tells us, "[...] spilled over and out of their ascribed, bounded roles, costumes and locales into the public streets" (p. 41), which not only obscured the previous distinction between classes, but also rendered the streets increasingly dangerous. Alan Sekula has suggested that, as a consequence, it became even more urgent to distinguish self from "other;" to be able to visually identify amongst the crowd of faces (the most available physical marker of difference in a crowd) who could be trusted and who might pose a threat. The new photographic medium, he argues, was perfectly suited to such an endeavour, [...] photography came to establish and delimit the terrain of the 'other,' to define both the 'general- 
ized look' - the typology - and the 'contingent instance' of deviance and social pathology. " (p. 7)

Used in tandem with the codes of portraiture established in the eighteenth century, the physiognomic method was particularly advantageous to "scientific" photography since it focused on the face of the deviant, rather than on his / her trappings. The traditional function of the portrait - " $[\ldots]$ the ceremonial presentation of the bourgeois "self'" (p. 6) - becomes degraded here: it delineates the "other," paradoxically, through a schema of "shared" difference. This schema relied in turn on the art historical tradition of representing insanity as bestial and potentially violent. Of course, the identification of insanity with aggressivity is not necessarily new. Rather, it is the ways in which photography was able (with the help of physiognomic and phrenological methods of identification) to construct a readily available visual blueprint from which to abstract mental and social aberrance. Indeed, even though photography's early pioneers' interests were not so much aesthetic as indexical, they depended for their coherence on an established aesthetic schema. The result - which is very much our legacy - has been to collapse social deviance and mental illness into one sinister visual typology. The criminal photographic archive thus gave birth to psychiatric photography, and to the idea that madness and criminality were complimentarily charted on a person's physiology.

If the visual typology of the insane is wild, the pathology is located not only in the mad-person's skull shape and size (as with eighteenth-century phrenology), but in her / his "look." The emphasis on "seeing" and violence cannot be overstated here since it is in the eyes that most representations tend to locate madness and aggression (one need only look at the après Papin photograph to see that this is so). In fact, it is often the fear of being "seen" by the madperson - being "noticed" by her / him - that induces much of the "normal" population's anxiety. The insane see differently, and they often see what isn't there (as with hallucinations ${ }^{4}$ ). In this visual dialectic of seeing and being seen, there is a sense of personal vulnerability we associate with the threat of violence, or loss of control. ${ }^{5}$ The 
mad person, we thus convince ourselves, is as identifiable by her / his comportment as (s)he is by her/his physical appearance. We can identify them and thus protect ourselves from them. The visual signs of the mad are then reassuring. They allow us to feel that we have some control over our environment, over the chaos we fear surrounds us. However, the reality is often quite different from the composite we have assembled from myth; from artistic representations; and from our everyday experience of the insane as recognizable in the stereotype of the bag lady/man (who is rarely, if ever, the perpetrator of violent crime).

Let us return now to the Papin photographs: the avant image of the Papins might thus be seen to constitute even more of a threat as a consequence of its codic or schematic normalcy. This image represents most clearly the traditional function of portraiture. It represents the two - despite their similar dress and coiffures - as discrete - that is, controlled — "selves." In the après image, on the other hand, it is difficult to determine which sister is which. They are no longer two sisters posing for a portrait, but one criminal type: unkept, unfocused, menacing. In the "before" image the horror is "that they are just like us;" that they do not signal to us their difference. The "after" photograph is therefore reassuring. It conforms to our idea of what madness looks like. But we must remember that the murders which took place before the women's incarceration and thus before the "after" image — were a shock to the community who knew the Papins as diligent workers and nice girls, and, likely, to the Lancelins who employed them. The sisters were considered hardworking, pleasant, church-going members of society - all of the markers of so-called normalcy. As Gilman points out with respect to the perpetrators of much violent crime, "Our shock is that they are really just like us." (1988, p. 13) This was not, then, a random act of violence enacted on strangers "by" strangers. The Lancelins knew their attackers; regarded them as normal (normal enough to have them live and work in their home); and confronted the sisters fearlessly. There was likely no visual apparatus in place to mark Christine and Léa as dangerous, otherwise the murders might not have taken 
Before

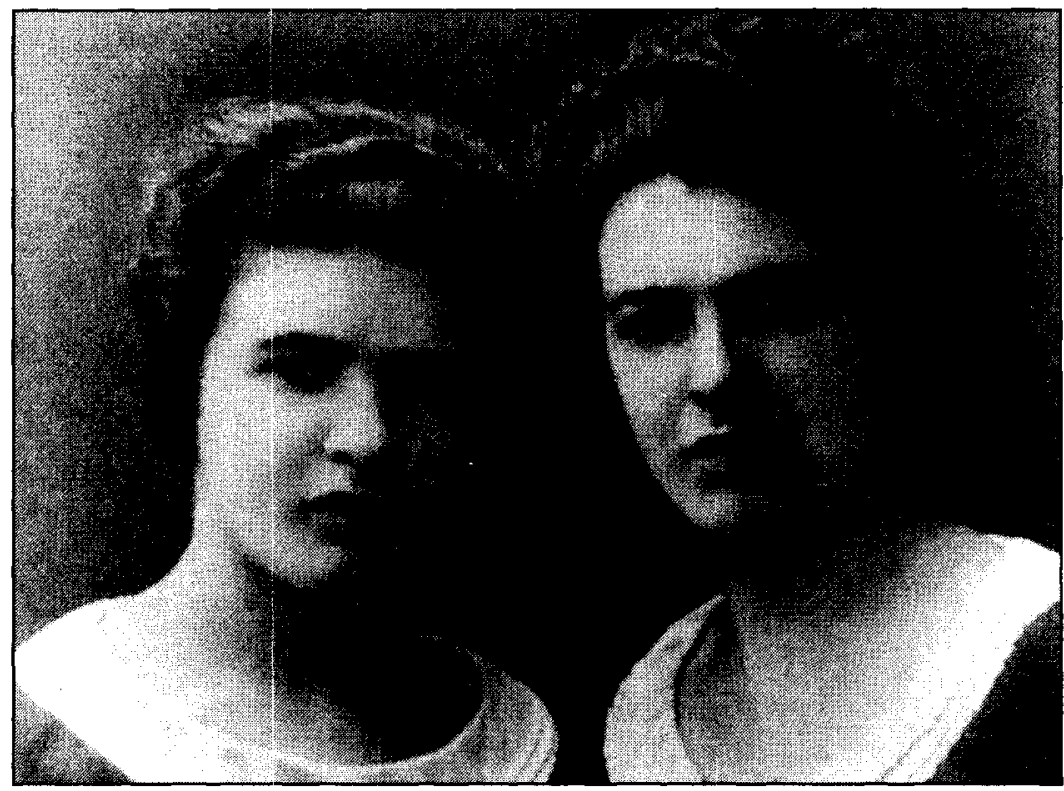

After

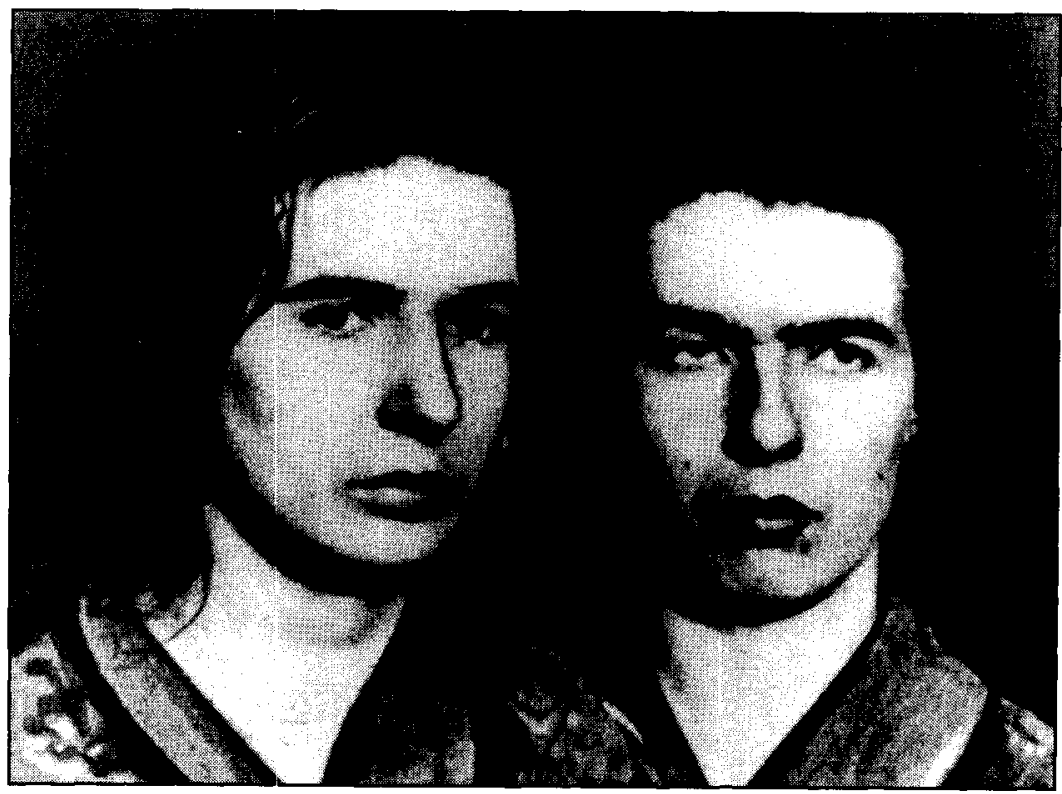

Originally from Le Surréalisme au service de la révolution 5 (1933)

The Photographic Insane 147 
place. Therefore, how do we explain the obvious visual pathology of the "after" photo?

As Gombrich has shown, pictures never transparently represent their subject. What they "do" represent is a schema of the cultural conception of a subject. Now, the photographic technique is especially well-suited to the operations of schemata. As an allegedly objective medium, photography promises to imbue our conceptual schemata with greater epistemological authority: it captures, after all, an actual moment in time. The problem with the Papin photographs (as with any photograph) is that we can never know all the circumstances surrounding the moment at which each photograph was taken and which inevitably contribute to the construction of each image. We can "hypothesize" as to why the sisters' appearance is so altered based on our understanding of the different conditions under which each photograph was taken: the "before" image was taken at the sisters' request; they had clearly prepared their attire carefully for the event, and they probably had an amiable exchange with the photographer (for whose services they would be paying). The "after" image, on the other hand, was taken after their incarceration. We can assume they were posed under duress and that there was little genial interaction between them and the photographer. Moreover, the purpose of the second photograph is quite clear: to show how murderous insanity has imprinted itself on the faces of the women. Even though it is, like most photographs of its kind, reliant on aesthetic codes, the image is not so much aesthetic as it is illustrative. The sisters are not willing subjects here. They do not look at the camera (perhaps they were even told not to), and unlike the first image, we can read no enjoyment of the moment in their postures.

The captions attached to the images also influence and direct our interpretation. If an image is devoid of any verbal commentary, or if it is unrelated syntagmatically to another image, it is more likely to be subject to interpretation. The avant and après titles then indicate an almost narrative transformation and inform the viewer as to how each image should be read. But viewing the two portraits separately, we would be unlikely to make the connection between the two women and their trans- 
formed counterparts without being told that the women depicted in each photo are the same. The after image depends for its coherence not only on established codes of deviance, but also on its relationship to the before image. In fact, it is easy to see how the after image has been manipulated to have the most effect on a viewer unfamiliar with the case. The sisters appear in the after photograph much as they appear in the before. In both images the sisters are dressed alike; Léa appears on the left and Christine on the right, and the backgrounds are contrived to highlight the faces of the women. Clearly, the sequential ordering of the images, and their similar composition, is designed to reinforce the effect of the "after" photograph; to reassure us that our schernatic framework is correct. But, as Christopher Lane says: "[...] chronology is deceptive here, for the photographs could easily be reversed with the distress of the 'after' incorporated into the apparent calm of the 'before'." (p. 24) Indeed. The "before image," we must remember, preceded the murders; it schematically conformed to the way in which the sisters "actually" looked. Their insanity, then, was not readily identifiable from their appearances; it only "becomes" readable once their deviance has already been established.

To conclude, this has not been an exhaustive foray into the photographic insane, as there are many other aspects of its production that have still to be considered. A larger project, for example, might expand its parameters to include a discussion of the ways in which instances of insanity are constructed in relation to the familiar triad of gender, class and racial identity. It is also significant to note that most recently - on the heels of much feminist achievement - films depicting female violence and insanity have captured the popular imagination. Beginning with Fatal Attraction, there have been a number of "psychotic women" movies which have culminated in what I believe to be the ultimate lethal woman film, Basic Instinct. Though the women's madness "is" visible in these films and is encoded in terms of what contemporary American culture finds most threatening -- the single, successful and sexually excessive woman - the purpose of filmic representations differs qualitatively from that of psychiatric representations. The important 
similarity, however, is in the fact that psychiatric photography and Hollywood cinema have each focused their attention on the woman who resides outside of the domain of masculine authority. This particular stereotype of the madwoman is well-known, as is the stereotype of the dangerous, racial other. These are components of psychiatric photography's history that have only been hinted at in this paper, but which are fodder for a more extensive and thorough undertaking. My intent here has been to stress the possible implications of visualizing madness, and, in light of Hollywood cinema's long preoccupation with mental illness, to provide a prolegomena toward an area of film research to be pursued more comprehensively in the future.

\section{McGill University}

\section{NOTES}

1 Michel Foucault, in The Birth of the Clinic: An Archaeology of Medical Perception (New York: Vintage Books, 1973) talks about the clinical gaze as one which " $[\ldots]$ refrains from all possible intervention, and from all experimental decision." (p. 108) The Foucauldian gaze, which is, in this instance, pre-Modern, is entirely objective. This is not to say that it resides outside the structures of perception of a viewing "subject" Instead, the gaze as Foucault describes it here is that of the observer who sees but does not intrude upon, and has no control over, what (s)he sees.

2 Such as lapses in discourse or garbled speech.

3 I use the word "look" here in the sense that Herbert Spiegelberg has used it in his essay "The Phenomenology of the Look" (Journal of the British Society for Phenomenology, vol. 20, $\mathrm{n}^{\prime \prime} 2,1989$ ). It is to be distinguished from perception and sight, and is also not to be wholly confused with appearance. It is a mode of "regarding" the world that — in the way I have used it - seems peculiar to the mad person. We might say the "look" can be ascertained in the eyes of the mad person, but it may also be the way in which the mad person "sees."

4 An excellent example of the "seeing insane" is to be found in contemporary Hollywood cinema. The psychotic characters in Seven (1995) and Copycat (1995), for example, force the characters (and the audience) to see their insanity by turning "murder into art" (or so goes the song in Copycat). In Copycat, the character reenacts famous historical murders modeled on photographs detailed in books on serial killers. The murderer in Seven represents a series of internal states through a succession of colour-coded, grisly, but artistic, tableaux. They are not themselves, then, visually identifiable by others as insane (which is what makes them so dangerous). Rather, it is the way in which they see (and force us to see) that brands them as mad (and criminal).

5 The seeing-and-being-seen dynamic is especially symbolic with respect to the Papin crime : the sisters' most heinous (and remarkable) feat was removing their victims' eyes with the optic nerves intact. Jacques Lacan (and others since) argued that such an act was inextricably linked to the sisters' paranoid experience of feeling sur- 
veyed. Enucleation, in this instance, temoved the objectifying, disciplining gaze of the Other.

\section{WORKS CONSULTED}

Bazin, André. "The Ontology of the Photographic Image," in Alan Trachtenberg (editor), Classic Essays on Photography. New Haven: Leete's Island Books (1980), p. 237-244.

Berber, John. Ways of Seeing. London: Penguin, 1972.

Crary, Johnathan. Techniques of the Observer: On Vision and Modernity in the Nineteenth Century. Cambridge: MIT Press, 1992.

Foucault, Michel. The Birth of the Clinic: an Archaeology of Medical Perception. New York: Vintage Books, 1973.

Foucault, Michel. Madness and Civilization: A History of Insanity in the Age of Reason. New York: Vintage, 1988.

Gilman, Sander L. Difference and Pathology: Stereotypes of Sextuality, Race, and Madness. Ithaca: Cornell University Press, 1985.

Gilman, Sander L. Disease and Representation: Images of Illness from Madness to AIDS. Ithaca : Cornell University Press, 1988.

Gilman, Sander L. The Face of Madness: Hugh W. Diamond and the Origin of Psychiatric Photography. New York: Brunner / Mazel, 1976.

Gilman, Sander L. Seeing the Insane. New York: John Wiley and Sons, 1982.

Gombrich, Ernst. Art and Illusion: A Study in the Psychology of Pictorial Representation. New York: Pantheon Books, 1960.

Gombrich, Ernst. "The Mask and the Face: the Perception of Physiognomic Likeness in Life and in Art," in E. H. Gombrich, Julian Hochberg, Max Black (editors), Art, Perception, and Reality. Baltimore: Johns Hopkins University Press (1972), p. $7-46$.

E. H. Gombrich. "Standards of Truth: The Arrested Image and the Moving Eye," in WJT Mitchell (editor), The Language of Images. Chicago: Chicago Unversity Press (1974), p. 181-217.

Hart, Lynda. Fatal Women: Lesbian Sexuality and the Mark of Aggression. Princeton: Princeton University Press, 1994.

Jay, Martin. Downcast Eyes: The Denigration of Vision in Twenticth-Century French Thought. Berkeley: University of California Press, 1994.

Lane, Christopher. "The Delirium of Interpretation: Writing the Papin Affair." Differences, vol. 5, n" 3 (1993), p. 24-62.

Mitchell, WJT. Iconology: Image, Text, Ideology. Chicago: University of Chicago Press, 1986.

Mitchell, WJT. The Reconfigured Eye: Visual Truth in a Post-Photographic Era. Cambridge: MIT Press, 1994.

Sekula, Allan. "The Body and the Archive." October, n" 39 (1986), p. 13-16.

Spiegelberg, Herbert. "The Phenomenology of the Look." Journal of the British Society for Phenomenology, vol. 20, n" 2(1989), p. 107-114.

Snyder, Joel. "Picturing Vision," in WJT Mitchell (editor), The Language of Images. Chicago: Chicago University Press (1974), p. 219-246.

Walkowitz, Judith R. City of Dreadful Delight: Narratives of Sexual Danger in LateVictorian London. Chicago: University of Chicago Press, 1992. 